\title{
KASVATUS\&AIKA
}

Arvostelu

https://doi.org/10.33350/ka.111874

\section{Neulanpistokudelma teinikuntatoiminnan historiaan}

\author{
Juhani Tähtinen
}

Arvosteltu teos: Jouhki, Essi 2020: Teinikuntatoiminnan sukupolvet: Muistitietohistoria oppikoulujen koululaisliikkeestä 1950-1970-luvuilla. Oulu: Oulun yliopisto. 372 s. http://urn.fi/urn:isbn:9789526225173

Jos sinua kiinnostaa menneen ajan koululais- tai nuorisoliikkeet tai jos haluat perehtyä oppikoululaisten tai nuorisokulttuurin historiaan, joudut lähes väistämättä tekemisiin myös Teiniliiton ja teinikuntien historian kanssa. Essi Jouhkin vuonna 2020 julkaistu historian väitöskirja Teinikuntatoiminnan sukupolvet: Muistitietohistoria oppikoulujen koululaisliikkeestä 1950-1970-luvuilla on tärkeä lisä tätä toimintaa valottavaan tutkimukseen. Tutkimuksen merkitystä lisää se, että Jouhki tarkastelee tutkimuksessaan teinikuntatoimintaa ja sen merkitystä teineille kahdelta paikkakunnalta, Iisalmesta ja Oulusta, koottuun muistitietoaineistoon tukeutuen. Paikalliseen toimintaan keskittyminen tuo tärkeän lisän aihetta koskevaan tutkimukseen, jota aiemmin on tutkittu ennen kaikkea teinitoiminnan valtakunnallisen katto-organisaation näkökulmasta. Jouhkin väitöstutkimuksen paikalliseen toimintaan ja toimijoihin liittyvä näkökulma tarjoaa teinikuntien toiminnasta aikaisempaa monipuolisemman ja moniäänisemmän kuvan. Paikallisten teinikuntien tarkastelu on siinäkin mielessä tärkeä, että teinitoiminta oli periaatteessa nuorten itsensä organisoimaa toimintaa, jonka merkitys oli etenkin 1960- ja 1970-luvun teiniaktivisteille tärkeää heidän identiteettinsä muovaajana, maailmankuvansa avartajana ja elämässä tarvittavien valmiuksien antajana. Tähän liittyvän "vaikutuksen" avaaminen onkin yksi tutkimuksen päätavoitteista.

Tutkimuksessa tarkasteltu ajanjakso 1950-luvulta 1970-luvun puoliväliin on monessa mielessä erityisen mielenkiintoinen niin paikallisten teinikuntien kuin valtakunnallisen teinitoiminnan kannalta. Näihin vuosiin osui useita teinitoiminnan uudelleen orientoitumisen kausia, joita tutkija tarkastelee teinisukupolvijaottelun avulla. Muutenkin näihin vuosikymmeniin osuu länsimaissa ja siten myös Suomessa uudenlaisen nuorisokulttuurin synty ja yleisemmin nuorison pyrkimys irtautua perinteisestä yhteiskunnan eetoksesta. Kuten Jouhkinkin tutkimus osoittaa, teinitoiminta oli vahvasti kiinni ajan murroksissa: alkujaan kansalaiskasvatuksellisesti orientoituneesta koululaisliikkeestä muokkautui ajan myötä kulttuurija yhteiskuntapainotteinen koululaisliike, jonka toimintaa leimasi erityisesti 1970-luvun alkupuolella toiminnan politisoituminen ja lukiolaisten "edunvalvontaan" suuntautuva toiminta. Tutkimuksessa tarkastelu päättyy surullisen kuuluisaan Teiniliiton "valojen sammuttamiseen" vuonna 1975, vaikka vuonna 1939 perustetun liiton toiminta päättyi lopullisesti vasta vuonna 1984. Käytännössä liiton ja teinikuntien toiminta hiipui 1970-luvun loppu- 
puolella lähes kokonaan, joten tutkittavan ajanjakson päättämistä Teiniliiton konkurssiin voi pitää perusteltuna.

Väitöskirjan rakenne noudattelee pitkälti yhteiskunnallisesti orientoituneen historiantutkimuksen rakennetta: raportin aloittaa laaja tutkittavaa ilmiötä, tutkimuksen asetelmaa ja tutkimusmenetelmiä avaava osio, itse aiheeseen päästään sivulta 86 alkaen. Vaikka nämä sivut ovat keskeisiä tutkimuksen aihepiirin ja tutkimuksen tarkastelukulman ja toteutuksen hahmottamiseksi, ainakin itse toivoin näitä sivuja lukiessani tekijältä hieman tiiviimpää kerrontaa. Toisen kerran raporttia lukiessani "tuomioni” oli tässä suhteessa paljon ensilukemaa lievempi, vaikka löysinkin tekstistä paikoin vieläkin tiivistämisen mahdollisuuksia. Tästä pienestä kritiikistä huolimatta, teoksen johdantoluvusta ja tutkimuksen teoreettisia ja menetelmällisiä lähtökohtia avaavasta kakkosluvusta lukija saa erityisen hyvät eväät syvempään jatkolukemiseen sekä tutkimuksen lähtökohtien tarkasteluun.

Tutkija määrittelee oman tutkimuksensa muistitietohistorialliseksi tutkimukseksi, jossa käytetään rinnakkain muistitietohistoriallisen ja perinteisen historiantutkimuksen lähestymistapoja. Tutkimuksen päälähdeaineisto koostuu 32 henkilöhaastattelusta tai paremminkin omaelämäkerrallisesta muistelusta. Muistitietotutkimukseen liittyen tutkija korostaa sitä, ettei hän pyri tutkimuksellaan perinteisen historian tutkimuksen lailla "faktilliseen historiaan", vaan pikemminkin tavoitteena on avata ja tulkita muistelijoiden tapahtumille antamia merkityksiä. Samalla tutkija korostaa, etteivät tulkinnat voi kuitenkaan olla täysin mielivaltaisia. Tämänkin vuoksi tutkimuksessa hyödynnetään muisteluaineiston lisäksi muutakin lähdemateriaalia perinteisen historiatutkimuksen tapaan. Tutkija nostaa esille historioitsijoille tyypilliseen tapaan haastattelujen ja muisteluiden tulkintojen kontekstoinnin tärkeyttä. Tulkintojansa uskottavuutta Jouhki on pyrkinyt vahvistamaan yhdistelemällä eri muistelijoiden tulkintoja ja tarkastelemalla niitä eri näkökulmista. Tässä, kuten yleensäkin kontekstoinnissa, tutkija on suoriutunut mallikkaasti.

Itse olisin toivonut, että Jouhki olisi avannut tehtyä perusteellisemmin muistitietohistoriallisen lähestymistavan ja perinteisemmän historiantutkimuksen välistä eroa, sekä sitä, miten hän on käytännössä näitä kahta traditiota tutkimuksessaan yhdistänyt. Itselleni tämä rajanteko jäi jonkin verran hämäräksi ja jäin sitä joissakin tutkimuksen kohdissa pohtimaan. Usein tällaiset rajanteot tahtovat jäädä hieman irrallisiksi ja päälle liimatuiksi. Jouhki ei onneksi sorru missään kohtaa ylilyönteihin, vaan hän pyrkii selkeästi rakentamaan näiden kahden tutkimusorientaation väliin vahvaa ja kestävää siltaa. Jouhki määrittelee osuvasti, kuinka muistitietohistorian tulkinnat rakentuvat muistelijoiden neulanpistomaisista mennyttä aikaa koskevista muistoista ja niille annetuista merkityksistä. Tutkijan tehtävänä on koota eri muistelijoiden "neulanpistoista" muodostuva kokonaistulkinta. Jouhkin mukaan näin muodostuva tulkinta menneisyydestä ja ihmisten merkityksenannoista sekä kokemusmaailmoista tulee mielenkiintoisemmaksi ja monisäikeisemmäksi kuin perinteisissä faktatodellisuuteen pyrkivissä historiantutkimuksen tulkinnoissa. Näin varmaan onkin, tai ainakin näin saadaan usein tulkintoihin enemmän syvyyttä ja erilaisia ulottuvuuksia kuin perinteisellä historiantutkimuksen lähdeaineistolla on mahdollista saada. Tämä ei kuitenkaan merkitse mielestäni perinteisemmän historian väheksymistä, vaan sitä tarvitaan "uusien historioiden" rinnalla edelleen.

Jouhkin tutkimuksen fokuksessa on paikallistason teinikuntien ja teinien toimintaan liittyvät muistot ja tulkinnat. Tässäkään tutkimuksessa ei voida kokonaan sivuuttaa valtakunnallisen tason eli Teiniliiton tarkastelua. Itse asiassa raportissa tarkastellaankin suhteellisen runsaasti Teiniliittoon liittyviä tai siinä mukana olleiden kokemuksia ja tulkintoja. Tätä selittää osin myös se, että paikallisen teinitoiminnan ja Teiniliiton toiminnan välinen suhde ja siihen liittyvä dialogi alkoi tutkijan mukaan muodostua tutkimuksen edetessä "erityisen 
mielenkiintoiseksi" tutkimuskysymykseksi (s. 36). Tämä on ymmärrettävää, muodostuihan Teiniliitosta 1960- ja 1970-luvun alkupuolella hyvin vahva lukiolaisten "edunvalvoja ja virallinen äänitorvi”, kuten tutkija asian ilmaisee. Johtuuko tästä ja yleensäkin suhteellisen laajasta muun lähdeaineiston käytöstä, että jäin toisin paikoin kaipaamaan sekä muistelijoiden "äänen" ja yleensäkin paikallisen näkökulman vahvempaa esilläoloa sekä muistelijoi den erilaisten tulkintojen tarkempaa avaamista ja tarkastelua. Onneksi tämä ei koske lähes kään kaikkia tarkasteltavia kysymyksiä ja tulkintoja. Osasyynä paikallisen näkökulman vähäisyyteen saattaa olla se, että haastateltavia oli tutkimuksen tavoitteita ajatellen suhteellisen vähän. Tutkija kuvaakin tarkkaan ja kattavasti, millaisia vaikeuksia hänellä oli löytää tutkimukseensa haastateltavia ja muistelijoita. Erilaisten keräysmenetelmien avulla muistelijoita tuli yhteensä 32, joista kaksi oli opettajia, jotka olivat aikanaan olleet paikallisessa teinitoiminnassa mukana. Loput 30 olivat entisiä teinejä, jotka jakautuivat suhteellisen tasaisesti tutkimuksessa esitetyn neljän teinisukupolven (ks. alla) kolmelle jälkimmäiselle kaudelle. Muistelijoiden määrän lisäksi myös omaelämäkerrallisen muisteluaineiston laadun on täytynyt asettaa omat rajoitukset sille, kuinka paljon tutkija on voinut tulkintoja tehdessään tukeutua muistelijoiden tuottamaan materiaaliin. Edellä nostettu kritiikki ei missään nimessä koske koko raporttia eikä kaikkien asioiden tulkintaa. Kaiken kaikkiaan tutkimus tarjoaa monipuolisen ja -äänisen kuvan paikallisen tason teinien ja teinikuntien toiminnasta, sen muutoksista ja siitä, millaisia merkityksiä muistelijat tälle muisteluhetkellä antoivat.

\section{Teinisukupolvitulkinta korostuu omassa luennassani}

Tutkimukselleen Jouhki määrittelee kolme pääkysymystä. Ensimmäiseksi hän kysyy, millaisia henkilökohtaisia kokemuksia teineillä oli aikansa teinitoiminnasta. Toiseksi tutkija pyrkii avaamaan tutkimuksellaan teinikuntatoiminnan paikallisen ja valtakunnallisen tason suhteen luonnetta ja merkitystä. Kolmas tutkimuksen pääkysymys liittyy teinikuntatoiminnan ja sukupolvien määrittelemiseen paikallisen tason muisteluaineiston pohjalta. Itselleni tutkimuksen tärkeimmäksi osaksi muodostui jälkimmäiseen kysymykseen liittyvien eri teinisukupolvien ja toiminnan muutosten kuvaukset sekä muistelijoiden niihin liittyvien merkitysantojen ja kokemusten tulkinnat. Tutkija itse toteaa mielenkiintoa herättävästi teinisukupolvitulkinnan olleen samanaikaisesti sekä tutkimuksen peruslähtökohta että sen keskeisin tutkimustulos. Tukija rakentaa oman sukupolvitulkintansa pitkälti aiempien valtakunnalliseen toimintaan liittyvien sukupolvitulkintojen pohjalta, tarkentaen niiden nimityksiä ja rajavuosia oman aineistonsa avulla. Näin tutkija on onnistunut muodostamaan toimivan kehikon aineiston tulkitsemiselle ja tulostensa raportoinnille.

Jouhkin teinisukupolville antamat nimet kertovat paljon siitä mistä kulloinkin oli kyse, ja myös toiminnan lähtökohtien muutoksista: ensimmäinen näistä kausista on nimetty "pioneerisukupolven" aikakaudeksi (1939-1949), tätä seurasi "kiltteyden ja kulttuurin sukupolvi" (1950-1962), kolmas teinisukupolvi on nimetty "kulttuurivalppaaksi ja yhteiskunnalliseksi sukupolveksi" (1963-1968) ja viimeinen tarkasteltu teinisukupolvi "puoluepoliittiseksi sukupolveksi" (1969-1975). Jouhkin tulkinta tuntuu hyvin perustellulta. Sen mukaan ensimmäisten teinisukupolvien toimintaa leimasi kasvattava ja kehittävä kerhotoiminta, joka oli linjassa vallitsevan yhteiskuntajärjestyksen ja -eetoksen kanssa. Sen sijaan kolmannen ja neljännen sukupolven aikana teinit ja teinikuntatoiminta ottivat vahvemmin etäisyyt- 
tä vallitsevaan yhteiskunnalliseen status quohon, ensin 1960-luvun kulttuuriradikalismin ja sittemmin poliittisen ja kansainvälisen solidaarisuuden toiminnan muodossa.

Toki kaikki lukiolaiset eivät olleet kulttuurisesti ja yhteiskunnallisesti aktiivisia eivätkä myöskään osallistuneet teinikuntien toimintaan, kuten tutkija oikein huomauttaakin. Tutkijan mukaan paikallinen tarkastelukulma nostaa paremmin kuin valtakunnallinen teinitoiminnan tulkinta esille sen, että teinikuntatoiminta oli luonteeltaan "kerrostunutta" (s. 329). Toisille nuorille teinitoiminta oli tärkeämpää kuin toisille. Etenkin teinitoiminnan viimeisen sukupolven aikana aktiivitoimijoiden ja rivijäsenten välillä toimintaan suhtautuminen alkoi erota toisistaan hyvinkin merkittävästi. Aika oli ajanut tämän kaltaisen nuorisoliikkeen toiminnan ohi monessa mielessä niin Suomessa kuin muualla länsimaissa. Tämä lukiolaisten ja teinien erilainen suhde teinikuntatoimintaan on hyvä pitää mielessä, kun tulkitaan eri aikojen teinikuntien toimintaa ja yleisemmin teini-ikäisten elämänpiirejä sekä yleistä orientaatiota. Vaikka Jouhki korostaa teinikuntatoiminnan kerroksellisuutta, on hän varmasti oikeassa siinä, kun toteaa tutkimuksensa tulosten edustavan suhteellisen hyvin muidenkin suomalaisten teinikuntien toimintaa.

Jouhkin mukaan kahden ensimmäisen teinikuntasukupolven toiminta oli luonteeltaan enemmän ekspressiivistä, kun puolestaan kahden jälkimmäisen teinisukupolven toimintaan liittyi aiempaa enemmän instrumentaalisia piirteitä ja tavoitteita. Tämä on tärkeä huomio. Teinitoiminnan kahden ensimmäisen kauden toiminta tähtäsi ennen kaikkea lukiolaisten henkisen ja fyysisen puolen sekä taitojen kehittämiseen, minkä lisäksi toiminnalla pyrittiin antamaan foorumi nuorten itseilmaisulle sekä omien rajojen löytämiselle ja koettelemiselle. Kahden viimeisen teinisukupolven aikana toimintaa määrittivät yhä enemmän sosiaalis-yhteiskunnalliset tavoitteet, joita liikkeen piirissä pyrittiin edistämään omalla toiminnalla, kuten taksvärkkitoiminnalla, tai ajamalla koululaisten asioita, kuten kouludemokratiaa kouluihin. Samalla teinikuntatoiminta alkoi ensimmäisen teinisukupolven lailla ohjautua enemmän teinien ulkopuolisista tekijöistä käsin. Tämä Jouhkin tulkinta on erittäin kiinnostava, jota tulisi tutkia enemmänkin. Voisiko tämän muutostrendin avulla tulkita tuon ajan tai miksei myös meidän aikamme nuorisoliikkeiden ja vastaavien toimintalogiikkaa ja tavoitteita yleisemminkin?

Edellä kuvatun teinisukupolvien tulkinnan lisäksi Jouhki tarkastelee väitöskirjan seitsemännessä luvussa sitä, miten haastateltavat ovat rakentaneet aikanaan ja sen jälkeenkin identiteettiään teinikuntatoiminnan ja niihin liittyvien muistojen kautta sekä sitä, minkälaisia henkilökohtaisia merkityksiä he liittivät näihin muistoihin. Jouhki pitää tähän liittyviä muisteluja keskeisenä osana tutkimustaan. Niin varmaan onkin. Tosin itse en oikein tavoittanut näihin tarkasteluihin liittyvien tulkintojen logiikka, vaikka ne sisältävätkin todella mielenkiintoisia nostoja ja tulkintoja. Itse olisin vienyt näiden teemojen käsittelyn eri teinisukupolvien tarkastelun yhteyteen, jolloin näitä tärkeitä teemoja olisi voitu käsitellä nyt tehtyä laveamminkin. Toki luvusta käy hienosti ilmi, kuinka tärkeää teinikuntatoiminta on haastatelluille aikanaan ollut ja on yhä edelleen. Erityisesti näin on ollut kahden viimeisen teinisukupolven ja teiniaktivistien kohdalla, oli kyse sitten johtamistaidoista, omasta julkiseen toimintaan osallistumisesta tai yleensäkin uskosta omien vaikutusmahdollisuuksien kehittymiseen. Rivijäsenmuistelijat korostivat puolestaan teinitoiminnan merkitystä nuorten yhtenäisyydentunteen ja sosiaalisten suhteiden lujittajana ja oman maailmankuvan avartajana. Tämä tulos on linjassa aiempien sukupolvi- ja nuorisotutkimusten kanssa.

Kaiken kaikkiaan Jouhkin väitöskirjatutkimus syventää merkittävällä tavalla aiempaa kuvaa 1950-luvun ja vuoden 1975 välisen ajan teinikuntatoiminnasta ja teiniyden merkityksestä lukiolaisille. Tutkija itse toteaa (s. 29) tutkimuksen avaavan "uuden näkökulman nuoruuden kokemusmaailman ja identiteettien rakentumisen tulkitsemiseen ja ymmärtämi- 
seen" sekä mahdollistavan nuorison omaehtoisen toiminnan vaikutusten ja merkitysten arvioimisen. Vaikka tässä voi olla vähän ylitulkintaa, tutkija on tässä suhteessa paljolti oikeassa, kuten myös siinä, kun hän korostaa nykyajan nuorison ja heidän toimintansa ymmärtämisen edellyttävän menneen ajan nuorten toiminnan ja nuoruuden historian tuntemusta. Tästä on helppoa olla samaa mieltä. Tutkimus liittyy omalta osaltaan keskusteluun, jota nykyäänkin käydään nuorison yhteiskunnallisista toimintamahdollisuuksista. Jouhkin mukaan tutkimus antaa meille eväitä tarkastella esimerkiksi nuorten yhteiskunnallisen aktivoitumisen ja osallistumisen mekanismeja historian näkökulmasta.

Essi Jouhkin tutkimuksen voi odottaa löytävän lukijoita niin nuorista, kouluista, kouludemokratiasta kuin nuorten omaehtoisesta toiminnasta kiinnostuneiden joukosta. Tähän väitöskirjaan kannattaa tarttua ihan ajan kanssa jo senkin vuoksi, että teos on hyvä esimerkki muistitietohistoriallisesta tutkimuksesta, minkä ansiosta teinitoiminnasta piirtyvä kuva saa uusia ja monivivahteisempia piirtoja.

KL Juhani Tähtinen toimii erikoistutkijana Turun yliopiston kasvatustieteen laitoksella. 